\title{
Quo Vadis, Opvoeder?
}

DIE STIGTING VAN S.A.V.B.O.

In die afgelope dekades is daar op die terrein van onderwys en opvoeding nogal heelwat tot stand gebring deur nuwe benaderings, klemverlegging, internasionale bevrugting, veral as die gevolg van uitgebreide navorsing. SuidAfrika neem ook sy aandeel aan hierdie modernisering: gedifferensieerde onderwys, opvoeding van begaafdes, verhoging van ouderdomsgrens vir verpligte onderwys, onderwys van kleuters, sosiale opvoeding, om net 'n paar te noem. Orals in ons land word opvoedkundige navorsing gedoen, deur ons baie onderwysdepartemente, deur buro's, deur universiteite, deur onderwyskolleges en deur ondernemende skole, skoolhoofde en indiwiduele onderwysers. Die materiaal wat op die wyse jaarliks tot die bestaande toegevoeg word, is nogal aansienlik. En tog, ondanks die mooi pogings, kon 'n buitelandse besoeker onlangs verklaar dat hy tevergeefs gesoek het na die tipies Suid-Afrikanse in die opvoeding (opvoedkunde). Onbevange beskou, was hy nie ver van reg nie. In ons oormatige, en dikwels kunsmatige gedesentraliseerdheid word die probleem na alle kante toe uiteengepluk sonder die nodige integrasie van bevindinge of selfs van pogings. Daar word allerweë hier 'n leemte gevoel.

Nou het daar op 27 September 1958 te Bloemfontein 'n byeenkoms van opvoedkundiges en opvoedkundige liggame en inrigtings plaasgevind wat hopelik bestem is om van historiese belang te wees. Op inisiatief van prof.
B. F. Nel van U.P. is die persone en instansies opgeroep om die stigting van 'n SUID-AFRIKAANSE VERENIGING VIR DIE BEVORDERING VAN OPVOEDKUNDE (S.A.V.B.O.) te oorweeg. Die twintigtal aanwesiges het $17 \mathrm{lig}$ game verteenwoordig, t.w. die Fakulteite van Opvoedkunde van 8 Universiteite, 4 Onderwyskolleges en 5 Onderwysersverenigings. Die aanwesiges was unaniem en geesdriftig oor die noodsaaklikheid van sodanige vereniging. Hulle het almal toegestem om as stigterslede op te tree en die beoogde vereniging gestig. 'n Tydelike werkkomitee is benoem om 'n konsep-konstitusie op te stel en om 'n konferensie van opvoedkundiges te beplan in die tweede helfte van 1959 met die volgende oogmerke: goedkeuring van 'n konstitusie, verkiesing van 'n permanente bestuur en wetenskaplike behandeling van die vraagstuk: „Die opleiding van onderwysers in Suid-Afrika".

Die doelstellinge van die vereniging kan kortliks as volg saamgevat word, na aanleiding van die formulering deur die werkkomitee:

(a) Die uitbouing van 'n eg Suid-Afrikaanse Opvoedkunde.

(b) Die bevordering van die wetenskaplike bestudering van die Opvoedkunde.

(c) Die aanmoediging van wetenskaplike navorsing op die gebied van die Opvoedkunde.

(d) Die bevordering en koördinering van navorsingsprojekte van nasionale belang. 
(e) Die aanknoping van kontakte met soortgelyke buitelandse opvoedkundige verenigings en met internasionale liggame t.o.v. die Opvoedkunde.

(f) Die regmatige verteenwoordiging van Suid-Afrika op internasionale byeenkomste rakende die Opvoedkunde.

(g) Die daarstelling van wetenskaplike publikasies op die gebied van die Opvoedkunde.

(h) Die verskaffing van advies met betrekking tot vraagstukke oor die onderwys en opvoeding.

Die indiwiduele lede van die vereniging moet aan sekere akademiese kwalifikasies voldoen, terwyl goedgekeurde liggame elk deur een stemgeregtigde lid verteenwoordig sal word. Die bedoeling is om hoegenaamd nie op die terrein van die bestaande onderwysersverenigings of navorsingsburo's te beweeg nie of ook nie om die Federale Raad van Onderwysersverenigings te vervang nie.

Suid-Afrika is hiermee besig om 'n baie groot agterstand te besef en pogings in die werk te stel om dit in te haal. In die V.S.A., Engeland en die meeste Europese lande bestaan daar reeds sedert jaar en dag sodanige verenigings, sommige al meer as ' $n$ halwe eeu oud. Dat dit meer as noodsaaklik geword het om so 'n stigting te onderneem, behoef geen verdere motivering nie. Waar hierdie stigting geskied het op die vooraand, soos ons vertrou, van 'n nuwe tydperk van nasionale of Uniale onderwysbeheer in ons land, word die strategiese belangrikheid verder beklemtoon. Daar is egter 'n lang en steil pad voor. Soos prof. dr. F. W. Prins van Rotterdam in 'n verslag oor hierdie stigting dit stel: „Mogen deze pioniers er eveneens in slagen de nodige fondsen te vinden, zodat het mogelijk zal zijn publicaties over de verichte onderzoekingen, een wetenschappelijk tijdschrift en een jaarboek voor Opvoeding en Onderwijs te doen verschijnen. De 27ste September 1958 was voor pedagogisch Zuid-Afrika een belangrijke dag". (Kopie verslag persoonlik ontvang.)

Ons begin maar klein en beskeie en wil ons weg geleidelik na groot hoogtes baan as dit ons beskore is. Hoe sterker die tipies Afrikaanse binne die geledere van die tipies Suid-Afrikaanse is, hoe duideliker kan die spore daarvan in die uiteindelike patroon gelê word. Die Calvinis het hier ook weer, soos so dikwels elders, 'n baie belangrike taak en roeping. Hoe beter die suurdeeg, hoe doeltreffender die deursuring.

B. C. SCHUTTE.

P.U. vir C.H.O. 